\title{
New Product Development and Marketing Strategies towards Customer Satisfaction (A Study of Dangote Nigeria Plc, North- East Zonal Office, Maiduguri Borno State Nigeria)
}

\author{
Dr. Abdulsalam Jibril, Abdulfatah Odua \\ Department of Business Administration, Adamawa State University, Mubi-Nigeria. \\ Department of Business Administration, Federal Polytechnic, Damaturu, Yobe State-Nigeria.
}

\begin{abstract}
The Study Titled: New Product Development Reasons and Marketing Strategy (A Study of Dangote Nigeria Plc, North-East Zonal Office, Maiduguri, Borno State) was carried out to identify what constitute new product, and looking at the attributes that constitute a product. The reasons why organizations introduce new products/services into the market other than for profit making which is the general belief by many organizations and the various marketing strategies that are applied to the products/services right from when it is introduced into the market up to the decline stage of the product. The study adopted the survey research design where six (6) respondents from Dangote Zonal Office were randomly and proportionately issued with questionnaires. The findings revealed that customer's need, want and taste are not usually seek before production; that organization does not plan their marketing strategy(ies) for these products. The study concluded by recommending among others that organization should seek consumer need, want and taste before embarking on production and management should have planned marketing strategy for the product at all level of its level of its life which will include pruning of brands, improve upon them, rename them to reflect improvement on them.
\end{abstract}

Keywords: New product, Marketing Strategy, Customer, Needs and Wants.

\section{Introduction:}

A product according to Kotler and Armstrong (2010) is "anything that can be offered to a market for attention, acquisition, use or consumption that might satisfy a need or want." They further added that product is more than just tangible objects, but also include service (intangible). Similarly, Kotler and Keller (2009) defined product as "anything that can be offered to a market to satisfy a want or need" they pointed out that it includes physical goods, services, experiences, events, places, persons, properties, organizations, information and ideas. Additionally, Lancaster and Massingham (2001) sees product as "anything or item that can be considered as a separate product entity and that may be distinguished in some way from other products that the company produces, irrespective o its relationship to those other products. "From the above it can be seen that the target of marketing is to satisfy human need and want at a profit. However, as the needs and wants of customer changes, marketer must ensure that they go into innovation of new products in other to meet with the changes in needs and wants of their customers.

Accordingly, Payola (1993) further pointed out reasons why an organization can lunch or manufacture a new product to include:

(I) To take advantage of market opportunity

(ii) To fight competition

(iii) To expand overall market through segmentation

(iv) To make use of excess capacity

(v) To use up obsolete materials and

(vi) When a product is at the decline stage. Jibril (2012) added that an organization equally can introduce a new product into the market with a view to stop imitation.

Lancaster and Massingham (2001) defined marketing strategy as "a means by which objectives are achieved". However, they gave a brief explanation that where objectives are specified as per what is to be done, and then strategy lays down how it is to be done. Furthermore, Kotler and Armstrong (2010) defined marketing strategy as "the marketing logic by which the company hopes to create his customer value and achieve its profitable relationships".

A) Introductory Stage: Onyebuagu (1995) and Kotler and Keller (2006) opined that the price of the product should be high in order to match demand against limited supply. Therefore, the strategy could be skimming the market. Further, they added that the quality of the product should be good in order to gain good reputation. More so, limited fund should be made available and be spent in communication with the target customers in a publication read by them. The newness of the product requires considerable effort in personal 
selling and sales promotion in addition to channel selection which will depend on the nature of the product related to.

B). Growth Stage: Osuagwu and Eniola (1997) and Kotler and Armstrong (2005) observed that this stage by the opportunity for profit, new competitors will enter the market, this will lead to the introduction of new product features and the market will expand paving way for an increase in the number of distribution outlets. However, the objective of the marketer is to gain an edge over possible competition through mass distribution, but avoid inviting competition. Further, they suggested price reduction for appealing to a wider range of the market should be applied while maintaining the quality of the product and appropriating a larger sum for the utilization of mass media. Additionally, Kotler and Armstrong (2005) opined that because of the emphasis on advertising, personal selling efforts should be extended to the servicing of channels of distribution while Departmental Stores should be engaged because they obtained a broad coverage of the market and yet saving the quality image.

C). Maturity Stage: Here, Kotler and Keller (2009) believed the price should be within competition level while the mass media must continue to be used for broad appeal in addition to a stronger emphasis on personal selling to obtain desired self space and to support advertising concepts and maintaining the same channels of distribution for preserving quality image. Again, they further suggested that the company should try and modify the product and marketing mix. The company should cut price to attract new users and competitors' customers. It can lunch a better advertising campaign or use aggressive sales promotions-trade deals, cent-off, and contests. The company can also move into larger market channels, using mass merchandisers.

D). Decline Stage: Kotler and Keller (2009) belief that the objective of the company at this stage is to prune product line as soon as it no longer makes a contribution to overhead, or as soon as a substitute product has been adopted which takes advantage o the new demand. Special prices are encouraged to support existing production and the company is expected to reduced emphasis on quality while it mind eliminate advertising or engage in reminder advertisement. Majorly, retraining of salesmen is needed, while discount houses for retraining largest possible market coverage of distribution channels should be encouraged. The suggestion that the strategies to be used at this stage of the product life cycle is the dropping of smaller market segment and marginal trade channels or the cut in production budget and reduction further in the price of the product (Kotler and Keller 2009). The management may decide to maintain its brand without change in the hope that competitors will leave the industry, or management may decide to reposition or reformulate the brand in hopes of moving it back into the growth stage of the product life cycle. In addition, management may decide to harvest the product, which means reducing various cost in plant and equipments, maintenance, research and development, advertising and sales force or they may further decide to prune the product from the line by selling it to another firm, or simply liquidate it at a salvage value. It should however be noted that keeping a weak product delays the search for replacement and creates a lopsided, product mix, hurts current profits and weakens the company's foothold on the future (Kotler and Keller, 2009).

In order to carry out this study, the following research questions are stated. Why organizations manufactured products and the reasons why they introduced products into the market. But what are the marketing strategies for these new products and how best does organization satisfy the customers? The significance of this study includes revealing the various reasons why organization (marketers) introduces products into the market. Additionally, it showed the marketing strategies applied at the various stages (life) of the product while in the market. The objectives of the study are;

i. To identify reasons for developing new products into the market.

ii. To identify the marketing strategy for the new products and how best to satisfy the customers. However, the scope of the study is restricted to new product development while the limitation includes; the field work aspect which require questionnaire administration, some of the respondents were not available to return the filled questionnaires, while fewer ones did not respond at all. Dangote Nigeria Plc, Maiduguri Depot, the company viewed releasing their company information as a means of using it against them.

\section{Area of Study/Methodology}

The study area is Maiduguri Metropolis, the capital of Borno State of Nigeria where the office of Dangote Zonal Office is located. It lies within latitude $10^{\circ} \mathrm{N}-14^{\circ} \mathrm{N}$ and Longitude $11^{\circ} 30^{\prime} \mathrm{E}$ and $14^{\circ} 45^{\prime} \mathrm{E}$. It occupies a total landmass of 50,7785qkm (Ministry of Land and Survey Maiduguri, 2009). It shares boundaries with Konduga Local Government Area in the North and Northeast and Jere Local Government Area in the South. This is the area where company is highly concentrated. According to National Population Census (2006) figure, Maiduguri has an estimated population of 521,492 people out of which 290,499 were male while 231,043 were female. It has an increasing international recognition as the centre of commerce, transport, education, religion and administration (Maxlock, 1976). 


\section{Methodology}

The target of the study was Maiduguri Zonal Office of Dangote Group Nigeria Plc which was established in 2000 with the aim of assisting in storing, selling and distribution of the varieties of brands manufactured by the company within the zone. A random selection of ten (10) respondents was carried out and six (6) respondents returned their questionnaire. The instrument used in gathering the data was questionnaire to reflect the objectives outline in the study. The respondents were asked to choose the options that best suit their opinions. Descriptive statistical analysis which involved the use of tables showing frequencies and percentages were adopted in the study.

\section{Results}

The result of the findings revealed among others is the following:

i). All the respondents that have decision to make in relation to the new product to be introduced by the company $(100 \%)$ are all Senior Staff of the company, again, it showed that the respondents are evenly distributed alone gender line $(50 \%-50 \%)$ and similarly showed that out of the six (6) respondents interviewed three (3) representing $50 \%$ have (3) spent an average of 5 years while the other three (3) also representing 50\% have spend an average of ten (10) year with the company, an indication which made all the respondents $(100 \%)$ agree that they are satisfied with the job. In addition to all the respondents $(100 \%)$ agreeing that the company deals with refined products tables $1,2,3,4$ and 5 .

ii). In addition, all the respondent $(100 \%)$ agree that at the moment there is a new product in the market e.g. to take advantages (1991), while $83.3 \%$ of the respondents representing five (5) of the six (6) respondents are of the view that the new brand satisfy customer market expansion (1993), expectation which is why the respondents evenly distributed re affirm that they are satisfied with the job the are doing. Again it revealed that $100 \%$ of the respondents agree that the customers are satisfied with the new brand on indication that six (6) $83.3 \%$ of the respondent agree is shown in the increase in the company turn over. Tables, 6,7,8,9 and 10 .

iii) Furthermore, the finding revealed that all the respondents (100\%) indicate that the idea of manufacturing a new brand emanates from the zonal office submission to the head office, while all also agree that two (2) there is synergy of idea between the zonal office and the head office on the would-be-new brand in addition to all six (6) respondents also agreeing that three (3) customer need, want and taste are sort before initiating a new product, just as all respondents (100\%) agreed that the company has a production department responsible for manufacturing the new brand and three a piss of the respondents again agreeing that customer taste, need and wants are sort through the channel members and through research and development department. Tables, $11,12,13,14$ and 15 .

iv) Again, if revealed that all the respondent (100\%) agree that improvement in the company/product meet customer taste, while the same percentage also agree that the company carry out after purchase action to determine whether the customers are satisfied with the company product/services. Furthermore, all the respondent confirm that dealers/salesmen that perform well are rewarded by the company, while the same $100 \%$ respondents agree that the company use salesmen both for the purpose of pushing the product in the market as well as gather information for decision making for the company, and all the respondents also agree that the company has there view and complain. Tables 16,17,18,19 and 20.

Table 1: Status of Respondents

\begin{tabular}{|l|c|c|}
\hline \multicolumn{1}{|c|}{ Respondent } & Frequency & Percentage \\
\hline Senior & 6 & 100 \\
\hline Junior & 0 & 0 \\
\hline Total & 6 & 100 \\
\hline
\end{tabular}

Source: Field Survey, 2013.

Table 2: Gender of Respondent

\begin{tabular}{|l|c|c|}
\hline \multicolumn{1}{|c|}{ Respondent } & Frequency & Percentage \\
\hline Male & 3 & 50 \\
\hline Female & 3 & 50 \\
\hline Total & 6 & 100 \\
\hline
\end{tabular}

Source: Field Survey, 2013.

Table 3: Year in service

\begin{tabular}{|l|c|c|}
\hline \multicolumn{1}{|c|}{ Respondent } & Frequency & Percentage \\
\hline $1-5$ years & 3 & 50 \\
\hline $6-10$ years & 3 & 50 \\
\hline Total & 6 & 100 \\
\hline
\end{tabular}

Source: Field Survey, 2013. 
Table 4: Questionnaire design to check job satisfaction level by staff

\begin{tabular}{|l|c|c|}
\hline \multicolumn{1}{|c|}{ Respondent } & Frequency & Percentage \\
\hline Yes & 6 & 100 \\
\hline No & 0 & 0 \\
\hline Total & 6 & 100 \\
\hline
\end{tabular}

Source: Field Survey, 2013.

Table 5: Questionnaire designed to check whether company deal with refined or unrefined products.

\begin{tabular}{|l|c|c|}
\hline \multicolumn{1}{|c|}{ Respondent } & Frequency & Percentage \\
\hline Refined & 6 & 100 \\
\hline Unrefined & 0 & 0 \\
\hline Total & 6 & 100 \\
\hline
\end{tabular}

Source: Field Survey, 2013.

Table 6: Questionnaire designed to know I there is a newly introduced brand into the market.

\begin{tabular}{|l|c|c|}
\hline \multicolumn{1}{|c|}{ Respondent } & Frequency & Percentage \\
\hline Yes & 6 & 100 \\
\hline No & 0 & 0 \\
\hline Total & 6 & 100 \\
\hline
\end{tabular}

Source: Field Survey, 2013.

Table 7: Questionnaire designed to check company view of customer satisfaction of new brand.

\begin{tabular}{|l|c|c|}
\hline \multicolumn{1}{|c|}{ Respondent } & Frequency & Percentage \\
\hline Yes & 5 & 83.13 \\
\hline No & 1 & 16.71 \\
\hline Total & 6 & 100 \\
\hline
\end{tabular}

Source: Field Survey, 2013.

Table 8: Questionnaire designed to reaffirm staff job satisfaction

\begin{tabular}{|l|c|c|}
\hline \multicolumn{1}{|c|}{ Respondent } & Frequency & Percentage \\
\hline Yes & 3 & 50 \\
\hline No & 3 & 50 \\
\hline Total & 6 & 100 \\
\hline
\end{tabular}

Source: Field Survey, 2013.

Table 9: Questionnaire designed to show customer dissatisfaction level.

\begin{tabular}{|l|c|c|}
\hline \multicolumn{1}{|c|}{ Respondent } & Frequency & Percentage \\
\hline Yes & 6 & 100 \\
\hline No & - & - \\
\hline Total & 6 & 100 \\
\hline
\end{tabular}

Source: Field Survey, 2013.

Table 10: Questionnaire designed to check the indicates for customer satisfaction

\begin{tabular}{|l|c|c|}
\hline \multicolumn{1}{|c|}{ Respondent } & Frequency & Percentage \\
\hline Increase in turnover & 5 & 88.3 \\
\hline Low turnover & 1 & 16.7 \\
\hline Total & 6 & 100 \\
\hline
\end{tabular}

Source: Field Survey, 2013.

Table 11: Questionnaire designed to check how new product ideas initiated by the head office.

\begin{tabular}{|l|c|c|}
\hline \multicolumn{1}{|c|}{ Respondent } & Frequency & Percentage \\
\hline Direct & - & - \\
\hline Through area office initiation & 6 & 100 \\
\hline Total & 6 & 100 \\
\hline
\end{tabular}

Source: Field Survey, 2013.

Table 12: Questionnaire designed to check if there is synergy of idea between the regional and head office what to produce.

\begin{tabular}{|l|c|c|}
\hline \multicolumn{1}{|c|}{ Respondent } & Frequency & Percentage \\
\hline Yes & 6 & 100 \\
\hline No & - & - \\
\hline Total & 6 & 100 \\
\hline
\end{tabular}

Source: Field Survey, 2013. 
Table 13: Questionnaire designed to know if customer need and wants is sort before product.

\begin{tabular}{|l|c|c|}
\hline \multicolumn{1}{|c|}{ Respondent } & Frequency & Percentage \\
\hline Yes & 6 & 100 \\
\hline No & - & - \\
\hline Total & 6 & 100 \\
\hline
\end{tabular}

Source: Field Survey, 2013.

Table 14: Questionnaire designed to know if the company has a production department.

\begin{tabular}{|l|c|c|}
\hline \multicolumn{1}{|c|}{ Respondent } & Frequency & Percentage \\
\hline Yes & 6 & 100 \\
\hline No & - & - \\
\hline Total & 6 & 100 \\
\hline
\end{tabular}

Source: Field Survey, 2013.

Table 15: Questionnaire designed to find out how company find out customer taste, want and need.

\begin{tabular}{|l|c|c|}
\hline Respondent & Frequency & Percentage \\
\hline Through channel members & 3 & 50 \\
\hline Through research and developmen3 & - & - \\
\hline Total & 6 & 100 \\
\hline
\end{tabular}

Source: Field Survey, 2013.

Table 16: Deigned to find out if improvement in company/product quality meets customer taste.

\begin{tabular}{|l|c|c|}
\hline \multicolumn{1}{|c|}{ Respondent } & Frequency & Percentage \\
\hline Yes & 6 & 100 \\
\hline- & - & - \\
\hline Total & 6 & 100 \\
\hline
\end{tabular}

Source: Field Survey, 2013.

Table 17: Designed to check after purchase action by company

\begin{tabular}{|l|c|c|}
\hline \multicolumn{1}{|c|}{ Respondent } & Frequency & Percentage \\
\hline Yes & 6 & 100 \\
\hline No & - & - \\
\hline Total & 6 & 100 \\
\hline
\end{tabular}

Source: Field Survey, 2013.

Table 18: Designed to check if dealers/salesmen are rewarded for performance.

\begin{tabular}{|l|c|c|}
\hline \multicolumn{1}{|c|}{ Respondent } & Frequency & Percentage \\
\hline Yes & 6 & 100 \\
\hline No & - & - \\
\hline Total & 6 & 100 \\
\hline
\end{tabular}

Source: Field Survey, 2013.

Table 19: Designed to find out if company use salesmen and dealers to push their product as well as gather information for decision making.

\begin{tabular}{|l|c|c|}
\hline \multicolumn{1}{|c|}{ Respondent } & Frequency & Percentage \\
\hline Yes & 6 & 100 \\
\hline No & - & - \\
\hline Total & 6 & 100 \\
\hline
\end{tabular}

Source: Field Survey, 2013.

Table 20: Designed to find out if company has addressed phone lines for customer's views and complain.

\begin{tabular}{|l|c|c|}
\hline \multicolumn{1}{|c|}{ Respondent } & Frequency & Percentage \\
\hline Yes & 6 & 100 \\
\hline No & - & - \\
\hline Total & 6 & 100 \\
\hline
\end{tabular}

Source: Field Survey, 2013.

\section{Discussion of Findings}

The findings of the study is based on the results obtained in tables $1-20$ which showed that all the staff in the Zonal Office are Senior staff. This goes to show that they are grounded in the ob and therefore can take decisions especially on new product. Again it revealed that the staff in the zonal office is evenly distributed along gender line. This factor will make it possible for actions taken and decision taken to reflect the view of 
all. Furthermore, the findings sowed that the staff in the zonal office are well experienced which is an indication that they are well knowledgeable as to the needs, wants and taste of the customer. Similarly, all the respondents agree that they are satisfied with their job. This is an indication that they are well committed to their jobs. This is an indication that they are well committed to their job. In addition, all the respondents agreed that the company deals with refined products. This enables the products/brands not to perish and prune on time.

Furthermore, the results revealed that the moment there is a new product in the market it is an indication that the company is expecting an increase in its profit through taking advantage of market opportunity. This is in agreement with Ayoola (1993). Again, majority of the respondents shared the view that the new products satisfy customer expectations. An indication noted by Ayoola, (1993) that organizations can develop new product in order to expand the market and stop imitation competitors Jibril (2012). Further, half of the respondents agree that they are satisfied with the job while half disagree. This is an indication that the company needs to seek for a means of striking a balance with those that are dissatisfied. All the respondents that agreed that the customers are satisfied with the new brand are indication that they should be expecting profit from the purchase that will be made from the customers.

In addition, all the respondents agree that the idea of developing new product among others emanates from submission and views sent to the head office from the zonal office. This is an indication that better products/brands will be developed because staff of the zonal office knows the customers better. The company also carries out offer purchase action as indicated by all the respondents; this will enable the company to know how satisfied or dissatisfied the customers are. More so, all the dealers/salesmen that perform well are usually rewarded by the company as indicated by all the respondents. This will spur the dealers/salesmen to increase their effort in selling. The findings revealed that the company uses the salesmen both for promoting the product in the market and for gathering information as indicated by all the respondents. This remedy is encouraging because it helps the company to fight competition. This finding is in line with Ayoola, (1993). Where there is rivalry between a company and its rivals, it serves as an avenue of information and intelligence gathering. All the respondents also indicated that the company has a feedback mechanism i.e. phone lines made available by the company for customers to air their views. This is very encouraging and a welcome idea because it serves as a means to show the company lagging areas.

\section{Conclusion}

From the foregoing, it can be concluded that competitor should be closely monitored especially at the marketing method periods so as to counter their move without negative effect to the competing brand. Again, customer satisfaction strategy should continuously be developed ahead of competitor's strategy, which will consider issues related to culture, religion, level of literacy, income e.t.c. Furthermore, it revealed organizations carry out post purchase action in order to determine whether the customers' are satisfied with the product purchased and used so as to carry out ameridment on them where it is noticed that they do not meet customer taste and preference.

\section{Recommendation}

Based on the research study on new product development and marketing strategies, the following recommendations are made;

1. Organization should continue to seek for the need, want and taste of the consumers before embarking on production of the goods and services needed by them in addition to developing good channels for customers to acquire the items easily.

2. The organization should design a way of compensating dissatisfied customer, (either by collecting the damaged or spoilt product and giving the customer a new one or collecting the damaged or spoilt product and making the customer to purchase on new one at a discount).

3. Again, the management should introduce an effective way of communication with the customers, especially the feedback channel from the customers. This will make the management know the feeling especially of dissatisfied customers.

4. In addition, the management should withdraw had brands, improve upon them and re-name them to reflect that there is improvement in them, and equally back them up with good promotion mid advertisement.

5. Finally, the management should time the period of introducing its new product into the market, i.e. should be done when workers salary is about to be paid so that the customers can include the purchase or trial of the new brand in their budget. 


\section{References}

[1]. Ayoola, P. (1993). Marketing Journal July 1992 - December 1993).

[2]. Jibril, A. (2012). Marketing Management and Strategy for MPhil; Business Administration, Adamawa State University, Mubi, (unpublished).

[3]. Kotler, P. \& Armstrong, G. (2010). Principles of Marketing, 13 ed, New Jersey Pearson Prentice Hall.

[4]. Kotler, P. \& Keller, K.L. (2009). Marketing Management, $13^{\text {th }}$ edition, New Jersey, Pearson Prentice Hall.

[5]. Lancastr, G. \& Massingham, L. (2001), Marketing Management, $3^{\text {rd }}$ edition, England, McGraw-Hill Publishing Company.

[6]. Maxlock, A. (1976). M. Maiduguri Master Plan, Maiduguri, Borno State Government Press, Maiduguri.

[7]. Ministry of Land and Survey, (2009) Maiduguri. Borno State Nigeria.

[8]. NPC (2006) National Population Commission, Federal Republic of Nigeria Official Gazette. Publication of Detail Breakdown pf the National and State Provisional Total Census. Printed and Published by Federal Government Printer, Lagos State, Nigeria. Vol.24(94).

[9]. Onyebuagu, C.S. (1995). Contemporary Marketing: Principles and Practice, Enugu, Global Ras Academic Publishers Ltd

[10]. Osuagwu, L. \& Eniola, V. (1997). Marketing Management; Principles, Strategy and Cases, Ikeja, Mai house Press Ltd. 